\title{
Phytochemical Screening and In vitro Evaluation of Pharmacological Activities of Aphanamixis polystachya (Wall) Parker Fruit Extracts
}

\author{
Apurba Sarker Apu*, Fariha Akhter Chowdhury, Farjana Khatun, A.T.M. \\ Jamaluddin, Atiqul Haque Pathan and Arindom Pal \\ Department of Pharmacy, East West University, Plot No-A/2, Main Road, Jahurul Islam City, Aftabnagar, Dhaka-1212, \\ Bangladesh \\ *For correspondence: E-mail: asa@ewubd.edu; Tel: +8809666775577 (Ext-115); Fax: +880-2-8812336
}

\begin{abstract}
Purpose: To investigate the crude $n$-hexane, ethyl acetate and methanol extracts of Aphanamixis polystachya fruit for their cytotoxic, antimicrobial, antioxidant and thrombolytic activities.

Methods: The fruit extracts were screened for major phytochemical compounds using in vitro established procedures. Antimicrobial and cytotoxic studies of the fruit extracts were conducted using disc diffusion and brine shrimp lethality bioassay methods, respectively, while an in vitro thrombolytic model was used to assess the clot lysis effect of the extracts with streptokinase as positive control. Antioxidant activity was evaluated by free radical scavenging activity using 2, 2-diphenyl-1picrylhydrazyl (DPPH) and nitric oxide assay as well as total phenolic content.

Results: The fruit extracts were a rich source of phytochemicals and among the extracts $n$-hexane extract showed highest antimicrobial activity against Shigella dysenteriae (zone of inhibition: $9.7 \pm 0.2$ $\mathrm{mm}$ ) and Candida albicans (zone of inhibition: $8.8 \pm 0.3 \mathrm{~mm}$ ) at a concentration of $1000 \mu \mathrm{g} / \mathrm{disc}$, whereas at the same concentration methanol extract showed highest zone of inhibition, $10.1 \pm 0.4 \mathrm{~mm}$, against Staphylococcus aureus. Compared to potassium permanganate with a median lethal concentration ( $\left.L C_{50}\right)$ of $13.23 \mu \mathrm{g} / \mathrm{ml}$ in the brine shrimp lethality assay, the $L C_{50}$ of $n$-hexane, ethyl acetate and methanol extracts were 15.77, 17.51 and $141.37 \mu \mathrm{g} / \mathrm{ml}$, respectively. All the extracts showed significant clot lysis activity $(p<0.001)$ with reference to negative control and \% clot lysis of the extracts were approximately 13. Notable antioxidant activity of the methanol extract was observed unlike the other extracts.

Conclusion: The results of the study demonstrated the potential cytotoxic, thrombolytic and antioxidant activities of the fruit extracts of $A$. polystachya and therefore further studies on the isolation and identification of active principles are required.
\end{abstract}

Keywords: Aphanamixis polystachya, Antimicrobial, Antioxidant, Cytotoxic, Thrombolytic, Phytochemical screening

Tropical Journal of Pharmaceutical Research is indexed by Science Citation Index (SciSearch), Scopus, International Pharmaceutical Abstract, Chemical Abstracts, Embase, Index Copernicus, EBSCO, African Index Medicus, JournalSeek, Journal Citation Reports/Science Edition, Directory of Open Access Journals (DOAJ), African Journal Online, Bioline International, Open-J-Gate and Pharmacy Abstracts

\section{INTRODUCTION}

The importance of medicinal plants in health care is not new. Aphanamixis polystachya of the Meliaceae family is a traditional plant with potential medicinal uses [1]. The large timber tree (sometimes shrub) with bunches of rounded lobular fruits and glossy deep brown seeds, is an aboriginal of most of the hotter parts of India, as well as the lowlands and hill forests of Bangladesh, Malay and Ceylon. The local names 
of Aphanamixis polystachya include Roina, Pitraj (Bengali); Rohitak, Pithraj (English), etc [1].

Ayurveda approves Aphanamixis polystachya ( $A$. polystachya) in liver and spleen disorders, tumors, ulcer, dyspepsia, intestinal worms, skin diseases, leprosy, diabetes, eye diseases, jaundice, hemorrhoids, burning sensation, arthritis and leucorrhoea [1]. The Santanol ethnic people of India employ the wood extract in healing cancerous wound [1]. The fruits are used as anthelmintic, laxative, refrigerant and is said to be useful against ulcers and rheumatism while the seed oil is used as a liniment in muscular pains [2]. Studies show that the stem bark extracts of $A$. polystachya has significant in vitro antibacterial, mild antifungal, cytotoxic and antioxidant effects $[1,2]$.

Antimicrobial assay procedures for medicinal plant extracts provide a valid measure of antibiotic activity. Among the methods, disc diffusion method persists in wide use as it is a simple and convenient method. Moreover, it requires only a minute amount of the test sample $(10-30 \mu l)$ [3]. Based on ethno-pharmacological literature, several species of medicinal plants are used in traditional medicine and have been screened for their cytotoxicity using brine shrimp lethality test. It is a simple, reliable, inexpensive and convenient method for the assessment of bioactivity of medicinal plants [3].

Antioxidants inhibit free radicals which are highly reactive, and also minimize oxidative damage, thus decreasing the risk of free radical-induced diseases which develop with aging. Medicinal plants with antioxidant property are being considered for use in antioxidant formulations [4]. 2, 2-diphenyl-1-picrylhydrazyl (DPPH) scavenging assay, nitric oxide scavenging activity, test for total flavonoid content, reducing power measurement, ferric reducing antioxidant power (FRAP) assay, cupric ion reducing antioxidant capacity, test for total phenolic content, etc are widely used to evaluate the ability of compounds to act as free radical scavengers and hence, antioxidant activity [5].

Thrombolytic agents are used to dissolve clot and in the management of thrombosis patients. Streptokinase is widely used as thrombolytic positive control efficiently for in vitro thrombolysis [6]. The thrombolytic activity of some plants have been studied using an in vitro model and significant thrombolytic activity were found for some medicinal plants, namely, Brassica oleracea, Capsicum frutescens, Nigella sativa [6], Aponogeton undulatus [7] .
The aim of the present study was to investigate the cytotoxic, antimicrobial, antioxidant and thrombolytic activities of $A$. polystachya fruit extracts.

\section{EXPERIMENTAL}

\section{Collection of plant material}

A. polystachya fruits were collected from Mymensingh, Bangladesh in February, 2011. The fruits were taken to the Bangladesh National Herbarium, Mirpur, Bangladesh, where their identity was confirmed by a taxonomist (Dr. Bushra Khan, Principal Scientific Officer) and a voucher specimen (Accession no. DACB-35449) deposited for future reference.

\section{Preparation and extraction of plant material}

The fruits were shade-dried and crushed into coarse powder using a mechanical grinder. The powdered material $(150 \mathrm{~g} \times 2)$ was successively extracted with $n$-hexane (APHE), ethyl acetate (APEA) and methanol (APME) by continuous hot extraction for $6 \mathrm{~h}$ using Soxhlet apparatus at a temperature not exceeding the boiling point of the solvent. The extracts were concentrated with a rotary evaporator (IKA, Germany) at low temperature $\left(40-50^{\circ} \mathrm{C}\right)$ and reduced pressure.

\section{Phytochemical screening}

Phytochemical screening of APHE, APEA and APME extracts was carried out qualitatively for the presence of alkaloids (Hager's test), flavonoids (modified ammonia test), steroids (Salkowski test), terpenoids (modified Salkowski test), reducing sugars (Fehling's test), saponins (frothing test), tannins (ferric chloride test), cardiac glycosides (Killer-Killani's test) and anthraquinones (chloroform layer test) [8].

\section{Antimicrobial screening}

The Kirby-Bauer disc diffusion method [3] was used to evaluate the antibacterial potential of $A$. polystachya fruit extracts on Gram-positive (Staphylococcus aureus) and Gram-negative bacteria (Shigella dysenteriae) and fungi (Candida albicans). Sterile $6 \mathrm{~mm}$ filter paper discs (Whatman no. 1) were impregnated with 500 and $1000 \mu \mathrm{g}$ of fruit extracts of each solvent system and dried in open air to evaporate the residual solvent. Standard ciprofloxacin discs (5 $\mu \mathrm{g} / \mathrm{disc}$ ) were used as positive control. Two sample discs of two different concentrations, standard antibiotic disc and blank disc (impregnated with solvents followed by evaporation) were placed gently on previously 
marked zones in the agar plates pre-inoculated with the test bacteria and fungi. After incubation of bacteria plates at $37{ }^{\circ} \mathrm{C}$ for $24 \mathrm{~h}$ and fungi plate at $25{ }^{\circ} \mathrm{C}$ for $48 \mathrm{~h}$, the antimicrobial activity of the test agents was determined by measuring the diameter of zone of inhibition expressed in $\mathrm{mm}[3]$.

\section{Brine shrimp lethality bioassay}

A. polystachya fruit extracts were screened for their cytotoxic activity using brine shrimp lethality bioassay [3]. For the experiment, $200 \mathrm{mg}$ each of the extracts was dissolved in dimethylsulfoxide (DMSO) and solutions of varying concentrations were obtained by serial dilution using simulated sea water. The solutions were taken in each premarked test tubes containing $5 \mathrm{ml}$ simulated seawater and 10 shrimp nauplii. After $24 \mathrm{~h}$, the numbers of survivors were counted and mortality (\%) was calculated for each dilution as well as for control. Simulated seawater containing varying quantities of DMSO was used as control. Potassium permanganate (KMN) was used as the positive control. An approximate linear correlation was observed when logarithm of concentration of test samples versus mortality (\%) was plotted. LC $_{50}$ value is the concentration of sample required to kill $50 \%$ of the shrimp and was determined using Microsoft Excel 2007.

\section{Assessment of total phenolic content}

The amount of total phenolic in the fruit extracts was measured as a way of determining antioxidant activity according to Folin-Ciocalteu procedure [9]. The plant extract $(20 \mathrm{mg})$ and $2 \mathrm{ml}$ $99.8 \%(\mathrm{v} / \mathrm{v})$ methanol were taken in a test tube and incubated at room temperature for $48 \mathrm{~h}$ in the dark; $2 \mathrm{ml}$ of the solution was transferred to a centrifuge tube and centrifuged at 5000 rpm for 5 min after which $300 \mu \mathrm{l}$ of the supernatant was mixed with $600 \mu \mathrm{l}$ of $10 \%$ Folin-Ciocalteu reagent and $2.4 \mathrm{ml}$ of $700 \mathrm{mM}$ sodium carbonate in a test tube and the mixture was incubated for 2 $\mathrm{h}$ at room temperature and the absorbance was measured at $765 \mathrm{~nm}$ in a UV-VIS spectrophotometer (Shimadzu, Japan). Total phenolic content was determined (as gallic acid equivalent) from a standard curve prepared with gallic acid.

\section{Determination of DPPH radical scavenging activity}

The free-radical scavenging activity of $A$. polystachya fruit extracts was measured by the decrease in the absorbance of the methanol solution of DPPH (2, 2-Diphenyl-1-picrylhydrazyl) [10]. A stock solution of DPPH (Sigma-Aldrich,
USA, $400 \mu \mathrm{g} / \mathrm{ml}$ ) was prepared in $99.8 \% \mathrm{v} / \mathrm{v}$ methanol (which gave an initial absorbance of 0.197 ) and $100 \mu \mathrm{l}$ of this stock solution was added to $5 \mathrm{ml}$ of a solution of $A$. polystachya extract of varying concentrations $(20-100$ $\mu \mathrm{g} / \mathrm{ml})$. The solutions were mixed properly, kept in the dark for $20 \mathrm{~min}$ and the absorbance measured at $517 \mathrm{~nm}$. Scavenging activity was expressed as inhibition (\%) as in Eq 1.

Inhibition $(\%)=\{(A c-A s) / A c\} 100$

where Ac is the absorbance of control and As the absorbance of the test sample.

Inhibition (\%) was plotted against the respective extract concentrations used and $\mathrm{IC}_{50}$ values were extrapolated from the plot. Ascorbic acid, an antioxidant, was used as positive control.

\section{Nitric oxide scavenging assay}

Sodium nitroprusside (5 mM) in phosphate buffered saline was mixed with various concentrations of the extract $(5-200 \mu \mathrm{g} / \mathrm{ml})$ dissolved in $99.8 \% \mathrm{v} / \mathrm{v}$ ethanol and incubated in the dark at room temperature for $2 \mathrm{~h}$. The solution $(2 \mathrm{ml})$ was mixed with $1.2 \mathrm{ml}$ of Griess reagent and the absorbance measured spectrophotometrically at $546 \mathrm{~nm}$ against blank (phosphate buffered saline). Ascorbic acid was used as a positive control and was treated in the same way as the extract [11]. Nitric oxide (NO) scavenging activity was computed as in Eq 2 .

$\mathrm{NO}(\%)=\{(\mathrm{Ac}-\mathrm{As}) / \mathrm{Ac}\} 100$

where Ac is the absorbance of control and As the absorbance of the test sample.

\section{In vitro thrombolytic study}

Median cubital venous blood $(3 \mathrm{ml})$ was drawn from 10 healthy volunteers ( 5 males and females each) who had not taken any oral contraceptives or anticoagulants in the preceding two weeks. The blood was transferred to 5 pre-weighed sterile Eppendorf tubes $(500 \mu \mathrm{l} /$ tube $)$ and incubated at $37{ }^{\circ} \mathrm{C}$ for $45 \mathrm{~min}$. After clot formation, serum was completely removed without disturbing the clot formed. Each tube having clot was again weighed to determine clot weight. The extract $(100 \mathrm{mg} / \mathrm{ml}, 100 \mu \mathrm{l})$ was added to the tube [7]. As positive control, $100 \mu \mathrm{l}$ of streptokinase (CSL Behring $\mathrm{GmbH}$, Germany, $3000,000 \mathrm{IU} / \mathrm{ml}$ ) was used $100 \mu \mathrm{l}$ of normal saline served as negative control. The tubes were then incubated at $37{ }^{\circ} \mathrm{C}$ for $90 \mathrm{~min}$ and observed for clot lysis. The released fluid was removed and the tubes again weighed to compute the difference in weight after clot 
disruption. The percentage difference in weight before and after clot lysis was expressed as clot lysis (\%).

\section{Statistical analysis}

Statistical comparisons were performed with Student's ' $t$ ' test using Microsoft Excel 2007. A $p$ value of 0.001 or less was considered to be significant. Mean \pm standard deviation (SD) was calculated for the parameters where applicable.

\section{RESULTS}

\section{Phytochemical profile of extracts}

Phytochemical screening of the extracts of $A$. polystachya fruits revealed the presence of various bioactive components of which alkaloids, flavonoids, steroids, terpenoids, saponins, tannins, cardiac glycosides and anthraquinones were the most prominent (Table 1).

\section{Antimicrobial activity}

The obtained values of the zone of inhibition (Table 2) were analyzed to find out whether $A$. polystachya fruit extracts have potential antimicrobial activity or not. APME at concentration of $1000 \mu \mathrm{g} /$ disc showed highest antimicrobial activity compared to other extracts. In case of bacteria and fungi, the zone of inhibition were ranges between 7-10 $\mathrm{mm}$ and 7-8 $\mathrm{mm}$ respectively.

\section{Cytotoxic activity}

Compared to positive control (potassium permanganate, $\mathrm{KMN}$ ), all the extracts tested showed good brine shrimp larvicidal activity (Table 3 ). The crude extracts that gave $\mathrm{LC}_{50}$ values $<100 \mu \mathrm{g} / \mathrm{ml}$ were considered significantly active and would therefore demand further investigation [13].

\section{Antioxidant activity}

The results of both the total phenolic content and free radical scavenging activity (DPPH and NO) of the crude extracts (Table 3) show promising antioxidant activity. The ethyl acetate extract exhibited the highest total phenolic content as well as high radical scavenging activity, comparable to that of ascorbic acid (AA).

Table 1: Phytochemical profile of extracts of $A$. polystachya fruit

\begin{tabular}{lcccc}
\hline Compounds & Test & APHE & APEA & APME \\
\hline Alkaloids & Hager's test & ++ & +++ & + \\
Anthraquinones & $\begin{array}{c}\text { Chloroform layer } \\
\text { test }\end{array}$ & - & - & + \\
Cardiac glycosides & Killer-Killani's test & +++ & +++ & + \\
Flavonoids & $\begin{array}{c}\text { Ammonia test } \\
\text { (modified) }\end{array}$ & +++ & +++ & +++ \\
Reducing sugars & $\begin{array}{l}\text { Fehling's test } \\
\text { Saponins }\end{array}$ & - & - & - \\
Steroids & Falking test & ++ & + & +++ \\
Tannins & Ferric chloride test & - & + & +++ \\
Terpenoids & $\begin{array}{c}\text { Salkowski test } \\
\text { (modified) }\end{array}$ & +++ & +++ & ++ \\
& & & & ++ \\
\hline
\end{tabular}

Key: $+++=$ highly present $++=$ moderately present $+=$ slightly present; - = absent; APHE, APEA and APME) denote $n$-hexane, ethyl acetate and methanol extracts, respectively.

Table 2: Antimicrobial activity of $n$-hexane (APHE), ethyl acetate (APEA), methanol (APME) extracts of $A$. polystachya fruit, positive control ciprofolxacin (CP) and negative control (respective solvents).

\begin{tabular}{|c|c|c|c|c|c|c|c|c|c|}
\hline \multirow{3}{*}{ Microbe } & \multirow{3}{*}{ Type } & \multirow{3}{*}{$\begin{array}{c}\text { Negative } \\
\text { control }\end{array}$} & \multicolumn{2}{|c|}{ APHE } & \multicolumn{2}{|c|}{ APEA } & \multicolumn{2}{|c|}{ APME } & \multirow{2}{*}{$\begin{array}{c}\text { CP } \\
(5 \\
\mu \mathrm{g} / \mathrm{disc})\end{array}$} \\
\hline & & & $\begin{array}{c}500 \\
\mu \mathrm{g} / \mathrm{disc}\end{array}$ & $\begin{array}{c}1000 \\
\mu \mathrm{g} / \mathrm{disc}\end{array}$ & $\begin{array}{c}500 \\
\mu \mathrm{g} / \mathrm{disc}\end{array}$ & $\begin{array}{c}1000 \\
\mu \mathrm{g} / \mathrm{disc}\end{array}$ & $\begin{array}{c}500 \\
\mu \mathrm{g} / \mathrm{disc}\end{array}$ & $\begin{array}{c}1000 \\
\mu \mathrm{g} / \mathrm{disc}\end{array}$ & \\
\hline & & & \multicolumn{7}{|c|}{ Zone of inhibition (mm) } \\
\hline $\begin{array}{l}\text { Staph } \\
\text { aureus }\end{array}$ & $\begin{array}{c}\text { Gram+ve } \\
\text { bacteria }\end{array}$ & - & $7.6 \pm 0.2$ & $8.8 \pm 0.3$ & $7.6 \pm 0.17$ & $9.5 \pm 0.3$ & $7.13 \pm 0.15$ & $10.1 \pm 0.40$ & $42.7 \pm 2.3$ \\
\hline $\begin{array}{l}\text { Shigella } \\
\text { dysenteriae }\end{array}$ & $\begin{array}{c}\text { Gram -ve } \\
\text { bacteria }\end{array}$ & - & $7.1 \pm 0.1$ & $9.7 \pm 0.2$ & - & $8.2 \pm 0.3$ & - & $8.7 \pm 0.2$ & $38.7 \pm 2.5$ \\
\hline $\begin{array}{l}\text { Candida } \\
\text { albicans }\end{array}$ & Fungus & - & $7.3 \pm 0.2$ & $8.8 \pm 0.3$ & - & $7.6 \pm 0.3$ & - & - & $49.3 \pm 1.5$ \\
\hline
\end{tabular}


Table 3: Cytotoxic and antioxidant activities, and total phenolic content of extracts of $A$. polystachya fruit

\begin{tabular}{|c|c|c|c|c|c|c|c|c|}
\hline \multirow[b]{2}{*}{ Extract } & \multirow{2}{*}{$\begin{array}{c}\mathrm{LC}_{50} \\
(\mu \mathrm{g} / \mathrm{ml}) \\
(n=3)\end{array}$} & \multirow[t]{2}{*}{$\mathbf{R}^{2}$} & \multicolumn{2}{|c|}{$95 \% \mathrm{Cl}$} & \multirow[b]{2}{*}{ Extract } & \multirow{2}{*}{$\begin{array}{c}\text { DPPH } \\
\text { radical } \\
\text { scavenging } \\
\text { activity } \\
\mathrm{IC}_{50}(\mu \mathrm{g} / \mathrm{ml})\end{array}$} & \multirow{2}{*}{$\begin{array}{c}\text { Nitric oxide } \\
\text { scavenging } \\
\text { assay } \\
\mathrm{IC}_{50}(\mu \mathrm{g} / \mathrm{ml})\end{array}$} & \multirow[b]{2}{*}{$\begin{array}{c}\text { Total } \\
\text { phenol (in } \\
\mathrm{mg} / \mathrm{g}, \\
\text { gallic acid } \\
\text { equivalent) } \\
(n=3)\end{array}$} \\
\hline & & & $\begin{array}{l}\text { Upper } \\
\text { limit }\end{array}$ & $\begin{array}{l}\text { Lower } \\
\text { limit }\end{array}$ & & & & \\
\hline APHE & $15.77 \pm 0.25$ & 0.953 & 16.05 & 15.48 & APHE & 65.78 & 77.82 & $34.73 \pm 5.05$ \\
\hline APEA & $17.51 \pm 0.50$ & 0.973 & 18.08 & 16.99 & APEA & 89.64 & 75.34 & $95.84 \pm 5.73$ \\
\hline APME & $141.37 \pm 1.20$ & 0.966 & 142.73 & 140.01 & APME & 71.56 & 58.63 & $69.16 \pm 6.36$ \\
\hline $\mathrm{KMN}^{*}$ & $13.23 \pm 0.87$ & 0.926 & 14.22 & 12.24 & $A A^{*}$ & 76.11 & 34.06 & --- \\
\hline
\end{tabular}

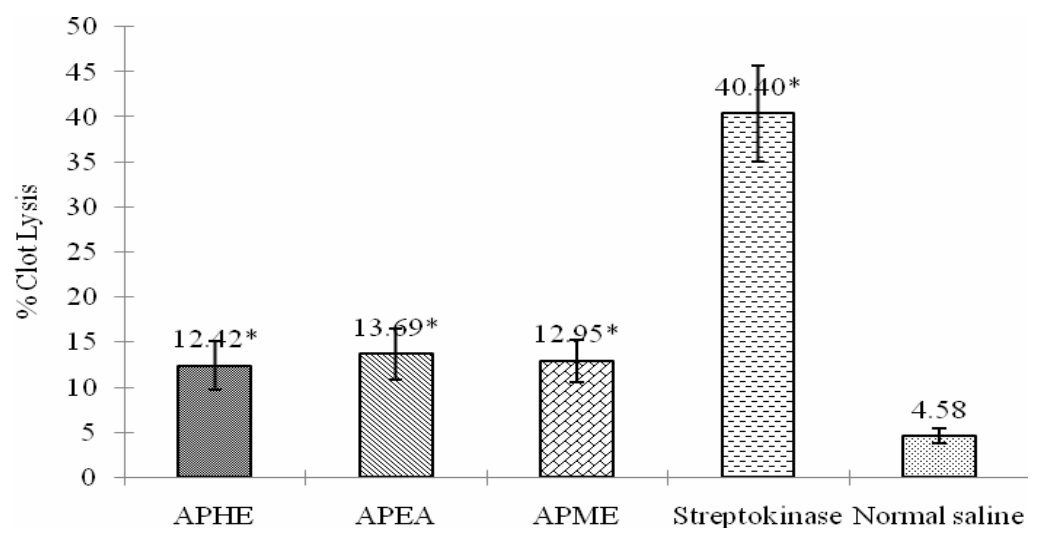

Figure 1: Clot lysis of blood samples of normal subjects by APHE, APEA, and APME extracts of $A$. polystachya fruit, streptokinase and normal saline $\left(n=10,{ }^{*} p<0.001\right.$, compared with negative control)

\section{Thrombolytic activity}

Maximum clot lysis was visually observed when streptokinase $(100 \mu \mathrm{l})$ was added to the clots The clot lysis data are shown in Figure 1. With normal saline, $4.58 \%$ clot lysis was seen, while $n$-hexane (APHE), ethyl acetate (APEA) and methanol (APME) extracts produced 12.4, 13.69 and $12.95 \%$ clot lysis, respectively $(p<0.001$, compared with negative control).

\section{DISCUSSION}

Previous studies [2,14-16] reported the presence of alkaloids, tannins, steroids, saponins, glycosides, flavonoids, anthraquinones and terpenoids in $A$. polystachya, and these are confirmed in part by own findings. The present study also correlates with the aforesaid studies. The presence of these secondary metabolite classes is known to have therapeutic activity against several diseases and therefore could suggest its traditional use for the treatment of various illnesses $[17,18]$.

The partial antibacterial activity of the extracts may be related to the presence of secondary metabolites such as terpenoids and saponins which are reported to have antibacterial activity
[19]. So APME extract demands further investigation, as it showed some evidence of being bioactive against Staphylococcus aureus.

Brine shrimp lethality is a general bioassay for the evaluation of cytotoxicity and some other biological activities [20]. The plant's cytotoxic activity may be due to the presence of alkaloids, flavonoids and terpenoids in $n$-hexane and ethyl acetate extracts of the plant fruit $[13,21]$.

The antioxidant activity of the extracts may be due to the presence of polyphenolic compounds such as flavonoids and tannins, and this, in turn, may be attributable to the hydrogen or electron donating ability of the groups present in the structure. This agrees with the findings of the other researchers [16] in respect of $n$-hexane and methanol extracts of $A$. polystachya. Therefore, the extracts could be used potentially for the prevention of free radical-mediated diseases.

Atherothrombotic diseases occur as serious impacts of the thrombus formed in blood vessels. Various thrombolytic agents are used to dissolve the clots that have already formed in the blood vessels; but these drugs have limitations and can lead to serious and sometimes fatal consequences [22]. In the present study, all the plant extracts showed moderate thrombolytic activity 
compared to negative control This activity may be due to the fact that the extracts are rich sources of alkaloids, flavonoids, tannins and terpenoids which are said to exert clot lysis activity $[11,23]$.

\section{CONCLUSION}

The fruit extracts of Aphanamixis polystachya showed significant cytotoxic and antioxidant activity. These extracts also possess partial antibacterial activity at higher concentration, and also moderate clot lysis activity. Based on these preliminary studies, further investigations are required to explore the bioactive molecules which are responsible for the extracts' activities as well as their mechanisms of action.

\section{ACKNOWLEDGEMENT}

The authors are grateful to Dr. Sufia Islam, Chairperson and Associate Professor, Department of Pharmacy, East West University, Dhaka, Bangladesh, for providing facilities and encouragement to conduct the work.

\section{REFERENCES}

1. Khan B. Encyclopedia of Flora and Fauna of Bangladesh. Dhaka: Asiatic Society of Bangladesh; 2008. 392 $393 p$.

2. Krishnaraju AV, Rao CV, Rao TVN, Reddy KN, Trimurtulu $G$. In vitro and in vivo antioxidant activity of Aphanamixis polystachya bark. Am J Infect Dis 2009; 5(2): 60-67.

3. Apu AS, Muhit MA, Tareq SM, Pathan AH, Jamaluddin ATM, Ahmed M. Antimicrobial activity and brine shrimp lethality bioassay of the leaves extract of Dillenia indica Linn. J Young Pharm 2010; 2(1): 5053.

4. Akhila S, Bindu AR, Bindu K, Aleykutty NA. Comparative evaluation of extracts of Citrus limon burm peel for antioxidant activity. J Young Pharm 2009; 1(2): 136140.

5. Arora DS, Chandra P. Assay of antioxidant potential of two Aspergillus isolates by different methods under various physio-chemical conditions. Braz J Microbiol 2010; 41(3): 765-777.

6. Anwar MS, Khan IN, Barua S, Kamal ATMM, Hosen SMZ Kawsar MH. Assessment of thrombolytic \& cytotoxic activity of herbal preparations originated from botanical source of Bangladesh. J App Pharm Sci 2011; 1(7): 77-80.

7. Chowdhury NS, Alam MB, Haque ASMT, Zahan $R$, Mazumder $M E H$, Haque ME. In vitro free radical scavenging and thrombolytic activities of Bangladeshi aquatic plant Aponogeton undulatus Roxb. Global J Pharmacol 2011; 5(1): 27-32.

8. Ghani, A. Medicinal Plants of Bangladesh. Chemical constituents and uses. Dhaka: The Asiatic Society of Bangladesh; 2003; pp 500-508.
9. Ainsworth EA, Gillespie KM. Estimation of total phenolic content and other oxidation substrates in plant tissues using Folin-Ciocalteu reagent. Nat Protoc 2007; 2(4): 875-877.

10. Howlader MA, Rizwan $F$, Sultana S, Rahman MR, Shams-Ud-Doha KM, Mowla $R$, Apu AS. Antimicrobial, antioxidant and cytotoxic effects of methanolic extracts of leaves and stems of Glycosmis pentaphylla (Retz.). J App Pharm Sci 2011; 1(8): 137-140.

11. Hoque N, Imam MZ, Akter S, Mazumder MEH, Hasan SMR, Ahmed J, Rana MS. Antioxidant and antihyperglycemic activities of methanolic extract of Glinus oppositifolius leaves. J App Pharm Sci 2011; 1(7): 50-53.

12. Smânia $A$, Monache $F D$, Smânia EF, Gil ML, Benchetrit LC, Cruz FS. Antibacterial activity of a substance produced by the fungus Pycnoporus sanguineus (Fr.) Murr. J Ethnopharmacol 1995; 45(3): 177-181.

13. Peteros NP, Uy MM. Antioxidant and cytotoxic activities and phytochemical screening of four Philippine medicinal plants. J Med Plants Res 2010; 4(5): 407414.

14. Chowdhury R, Rashid RB. Effect of the crude extracts of Amoora rohituka stem bark on gastrointestinal transit in mice. Indian J Pharmacol 2003; 35: 304307.

15. Jagetia GC, Venkatesha VA. Treatment of mice with stem bark extract of Aphanamixis polystachya reduces radiation-induced chromosome damage. Int $J$ Radiat Biol 2006; 82(3): 197-209.

16. Sarla S, Prakash MA, Apeksha R, Subhash C. Free radical scavenging (DPPH) and ferric reducing ability (FRAP) of Aphanamixis polystachya (Wall) Parker. Int J Drug Dev Res 2011; 3(4): 271-274.

17. Hassan MM, Oyewale AO, Amupitan JO, Abduallahi MS, Okonkwo EM. Preliminary phytochemical and antibacterial investigation of crude extracts of the root bark of Detarium microcarpum. J Chem Soc Nigeria 2004; 29(1): 26-29.

18. Usman $H$, Osuji JC. Phytochemical and in vitro antimicrobial assay of the leaf extract of Newbouldia leavis. Afr J Tradit Complement Altern Med 2007; 4(4): 476-480.

19. Daisy $P$, Mathew $S$, Suveena $S$, Rayan NA. A novel terpenoid from Elephantopus scaber-antibacterial activity on Staphylococcus aureus: A substantiate computational approach. Int J Biomed Sci 2008; 4(3): 196-203.

20. McLaughlin JL, Chang CJ, Smith DL. "Bench-top" bioassays for the discovery of bioactive natural products: an update. In: Rahman $A$, editor, Studies in natural product chemistry. $9^{\text {th }}$ ed. Amsterdam: Elsevier; 1991; pp 101-103.

21. Mazumder PM, Das S, Das S, Das MK. Cytotoxic activity of methanolic extracts of Berberis aristata $D C$ and Hemidesmus indicus R.Br. in MCF7 cell line. J Curr Pharm Res 2010; 1: 12-15.

22. Mannan A, Kawser MJ, Ahmed AMA, Islam NN, Alam SMM, Emon MAEK, Gupta SD. Assessment of antibacterial, thrombolytic and cytotoxic potential of Cassia alata seed oil. J App Pharm Sci 2011; 1(9): 56-59.

23. Dwivedi S. Terminalia arjuna Wight \& Arn.- A useful drug for cardiovascular disorders. J Ethnopharmacol 2007; 114(2): 114-129. 